
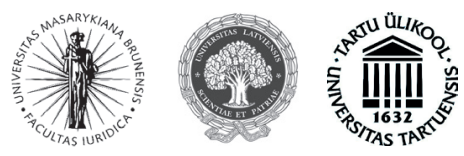

\title{
DISSOLUTION OF PARLIAMENT IN LATVIA: LEGAL REGULATION AND PRACTICE
}

\author{
Annija Kārkliņa \\ University of Latvia, Faculty of Law \\ Raina boulevard 19, Riga, LV-1050 \\ Telephone: (+ 371) 67034560 \\ E-mail: Annija.Karklina@lu.lv
}

Received on 31 July, 2013; accepted on 20 September, 2013

doi:10.13165/JUR-13-20-3-18

Abstract. The article analyses the regulation for premature termination of the Parliament in Latvia. The introductory part of the article provides a short characteristic of the Constitution of Latvia - the Satversme adopted in 1922, and outlines the basic principles of legal regulation of the Parliament, i.e. the Saeima.

Further chapters of the article analyse historic development of the premature termination of the Parliament. On 15 February, 1922, when the Satversme was adopted, only one mechanism for the premature termination of the Parliament was established there: dissolution of the Saeima. However, relatively recently, in 2009, after a prolonged public discussion another mechanism for the premature termination of the activity of the Saeima was established, which was the recall. ${ }^{1}$ Both models of the termination of the activities of the Parliament are analysed in the article by specifying the principal differences between them. Along with the analysis of the provisions of the Constitution and theory, the practice of dissolution of the Saeima is characterised as well, because in 2011 the Parliament (the Saeima) was dissolved in a constitutional way for the first and so far the only time in the history of Latvia and extraordinary elections were held.

1 The amendment entered into force on 2 November, 2010, i.e. on the day of convening the new convocation of the Saeima. 
Keywords: parliament, the Saeima, dissolution of parliament, recall of parliament, parliamentary mandate, the State President, the Constitution.

\section{Introduction}

As concluded by the scientists of law, historically in many countries there was a perception that premature termination of authority of the Parliament was an undesirable phenomenon, as well as in Latvia in the twenties of the 20th century, when the text of the emerging Constitution was discussed, there was a strong predisposition formed that the dissolution of the Parliament was something negative and it showed only an intention of some person to establish dictatorship. ${ }^{2}$ However, notwithstanding various discussions, the developers of the Constitution, the fathers of the Satversme, when adopting the Satversme in 1922, established in it the mechanism for the premature termination of the Parliament, the dissolution of the Saeima, and this regulation has remained unchanged until today.

The mechanism for the dissolution of the Saeima that has been established in Section 48 of the Satversme sets forth that the President is entitled to propose the dissolution of the Saeima and the national vote must be organised afterwards, in which the electorate would decide whether the Saeima should be dissolved, or the President would be dismissed. Thus, a quite unusual mechanism for the dissolution of the Parliament was established in Latvia, which is characterised as a specific one by many foreign scientists of law. In their turn, Latvian scientists of law had expressed the doubt whether such mechanism for the dissolution of the Parliament would be ever implemented in practice. Notwithstanding the initial scepticism, the dissolution of the Saeima is a mechanism in Latvia that has already been applied in practice, because the national vote on the dissolution of the Saeima took place in 2011 based on the proposal of the President.

During both the so-called first independence and after renewal of independence of Latvia, from time to time the public has expressed dissatisfaction with the work of the representatives of the nation, including asking the President to initiate the referendum for the dissolution of the Saeima; however, considering the aforementioned specifics of procedure for the dissolution of the Saeima, during the recent years the electorate has increasingly actively insisted that the electorate itself would be provided with the possibility to commence the procedure for the premature termination of the authority of the Saeima, without waiting until such procedure will be initiated by the President. In 2009, after various political events, the Saeima amended the Satversme by establishing in it one more mechanism: the procedure for recalling the Saeima, implementation of which is in the hands of the electorate only, i.e. $1 / 10$ of the electorate having the right to request holding a referendum for the premature termination of the authority of the Saeima (Section 14 of the Satversme). 
The purpose of the article is familiarising the reader with both mechanisms for the premature termination of the Parliament by analysing their legal regulation as well as outlining the principal differences between these mechanisms and the problems in practice of the dissolution of the Saeima. It is known that an increasing role in the modern science of law is played by the comparative research method, therefore, the publication may serve scientists and practitioners of law from other countries as well, when in such countries, eventually, the discussion will emerge on the need to amend the mechanism for the dissolution of the Parliament set forth in the Constitution, and based on the experience of Latvia it will be possible to draw conclusions with respect to advantages and shortcomings of such regulation. Moreover, as it is evident from the experience of other countries, the dissolution of the Parliament or its individual Chambers is not unusual nowadays. The dissolution of the Parliament is even required if there is a serious concern that the wishes of the Parliament do not match the wishes of the nation. The dissolution of the Parliament should be regarded as an appropriate aid for solving the national crisis and serious crisis of parliamentary nature.

In parallel to the above mentioned statements, the article outlines the fact that in modern Latvia there is an increasing number of mechanisms, whereby the electorate may influence political processes in the country and the regulation set forth in the Constitution, because, as noted above, thanks to the initial initiative of public organisations to grant the right to initiate the issue on recalling the Saeima also to the nation itself, the respective amendments were made to the Satversme and the electors were granted the right to initiate recalling of the Saeima.

The analytical research method is mainly used in the article for analysing the content of legal provisions and the practice of their application, as well as the historic research method, by means of which the historic development of the legal regulation is depicted from the moment of adoption of the Satversme until the present day.

\section{An Introduction to the Constitutional System and Regulation of the Parliament of Latvia}

Latvia is a unitary parliamentary republic, which was proclaimed on 18 November, 1918. In 1920, the process of elaboration of the country's constitution was started. The Constitution was worked out by the Constitutional Assembly, the first elected Latvian parliament, which was elected by the nation in general and direct elections, in which both genders were represented - at that time it was still a rare phenomenon. ${ }^{3}$

On 15 February, 1922, the Constitutional Assembly adopted the Constitution of the Republic of Latvia - the Satversme. The Satversme is still the constitution of the Republic of Latvia - the document with the highest legal force.

3 See: Iljanova, D. The Constitutional Law of the Republic of Latvia. In: Constitutional Law of 10 EU Member States. The 2004 Enlargement. Kluwer Law International, 2006, p. v-3. 
In the beginning of the $90 \mathrm{~s}$, i.e., after the restoration of independence from the USSR, adoption of a new constitution of Latvia was discussed, but a decision was made to renew the Constitution (Satversme) of 1922. Since 6 July, 1993, i.e., the date when the Constitution fully regained its force, it has been prescribing the constitutional order of the Republic of Latvia. Thus, the Constitution of the Republic of Latvia is one of the oldest still existing European national constitutions.

Over time, the Satversme has undergone various amendments. Since its adoption in 1922 until now, the Satversme has been amended 11 times. The largest and the most significant amendments are the ones adopted in 1998, supplementing the Satversme with Chapter 8 "The Fundamental Human Rights". Over the years, the amendments have affected all the Chapters of the Satversme, including the regulation of the Parliament of the Republic of Latvia - the Saeima. This article describes in detail the issue of the regulation on early termination of the mandate of the Saeima and its practice in Latvia, as in 2011 for the first and so far the only time the Parliament was dissolved and early elections were held.

The Parliament of the Republic of Latvia - the Saeima - is a single-chamber Parliament consisting of 100 representatives of the people (deputies). The rules of the Saeima are defined in Chapter 2 of the Saeima "The Saeima" and Chapter 5 "Legislation".

The Saeima is elected in general, equal, direct, secret and proportional elections for 4 years. Before the adoption of the Amendments to the Saeima in 1997, the length of the parliamentary mandate was 3 years, which was one of the shortest parliamentary terms in the world. The elections for the Saeima are held on the first Saturday in October. Like it is in most other countries, the Latvian parliament can be dissolved. In Latvia, there are two different mechanisms for the early termination of the parliamentary term - dissolution and recalling. Hereafter, the article will deal with both these procedures.

\section{Dissolution of the Saeima}

The dissolution of the Saeima shall take place in accordance with Article 48 of the Satversme. This regulation has been effective since the adoption of the Satversme in 1922.

Article 48 of the Satversme states: "The President shall be entitled to propose the dissolution of the Saeima. Following this proposal, a national referendum shall be held. If in the referendum more than half of the votes are cast in favour of dissolution, the Saeima shall be considered dissolved, new elections called, and such elections held no later than two months after the date of the dissolution of the Saeima." This Article is closely related to Article 50 of the Satversme, which states: "If in the referendum more than half of the votes are cast against the dissolution of the Saeima, then the President

4 Until then, the regulation of human rights was not included in the Satversme, except for certain fundamental rights, such as the right to vote in elections of the Saeima.

5 Law Satversme of the Republic of Latvia. Latvijas Véstnesis. 1993, No. 43. 
shall be deemed to be removed from office, and the Saeima shall elect a new President to serve for the remaining term of office of the President so removed."

These rules on the dissolution of parliament differ significantly from those of other countries. The expert on Russian constitutional law Sakharov indicated that comparing the Latvian legislation with that of other countries the rules on the dissolution of the Saeima in Latvia are quite unusual. ${ }^{6}$

The uniqueness of this model manifests itself in two aspects. First, unlike many other countries, where the head of the state dismisses the parliament, the President of Latvia shall be entitled only to initiate a referendum on the dissolution of the Parliament. Secondly, the President, proposing a referendum, runs the risk of losing his office, as Article 50 of the Satversme stipulates that if in the referendum more than half of the votes are cast against the dissolution of the Saeima, then the President shall be deemed to be removed from office. Consequently, such a referendum will have an alternative outcome - either the President or the Saeima will be dismissed.

The dissolution of the Saeima consists of several phases:

1) The President of the State has the right to propose the dissolution of the Saeima. In order to propose the dissolution of the Saeima, the President has in no way limits and conditions. Theoretically, he does not even have to justify why he proposes to dissolve the Saeima - the legislation does not require to reveal the reasons for dismissal. The President's proposal is an order in accordance with the Saeima - this is one of the rare occasions, when the presidential order does not require countersigning (countersign of the Prime Minister or Minister).

2) On the basis of the presidential order, the Central Election Commission is required to prepare a referendum on the dissolution of the Saeima.

3) If in the referendum more than half of the votes are in favour of the dissolution of the Saeima, the Saeima shall be considered dissolved and no later than two months after the date of the dissolution new parliamentary elections shall be held.

4) If in the referendum more than half of the votes are cast against the dissolution of the Saeima, then the President shall be deemed to be removed from office, and the Saeima shall elect a new President to serve for the remaining term of office of the President removed.

Theoretically, the voters can request the President that he proposes to dismiss the Saeima, but for the President of the State such a request will not be legally binding. ${ }^{7}$

The Latvian authoritative expert on law, the professor Dišlers, when analyzing procedures for the dissolution of parliament provided by Article 48, stated: "It is doubtful if the proposal to dissolve the Parliament will become an institute applicable to real life. / .. /.. ${ }^{8}$ Other modern scholars expressed similar assumptions, but these predictions have not come true, as on 28 May, 2011, the President Valdis Zatlers made the Order No. 2

6 Saharov, A.H. Institut Prezidenstva v Sovremennom Mire [The Institute of President in Contemporary World]. Moskva: Juridicheskaja Literatura, 1994, p.129.

7 Pleps, J. Kādā Veidā Var Atlaist Saeimu. Jurista Vārds. 2003, 45(301): 3-6.

8 Dišlers, K. Ievads Latvijas Valststiesību Zinātnē. Rīga: A. Gulbis, 1930, p.177. 
"On Initiating the Dissolution of the Saeima". 9 On the basis of this order, on 30 May, 2011, the Central Election Commission announced the Referendum on the dissolution of the 10th Saeima, and on 23 July, 2011, it held the Referendum on the dissolution of the 10th Saeima. Voter turnout in the Referendum was 44.73 percent. 94.3 percent of the voters voted affirmatively for the dissolution of the 10th Saeima, while only 5.48 percent of the voters voted against the dissolution of the 10th Saeima. ${ }^{10}$ Thus, in 2011 , for the first time in the history of Latvia, the Saeima was dismissed in a constitutional way. $^{11}$

Unlike other cases of the referendum ${ }^{12}$, the referendum on the dissolution of Parliament does not require quorum. Even in the case of participation of only some voters, a referendum would be considered to have taken place and they would decide which of the constitutional organs - the President or the Parliament - shall be dismissed. This regulation contains a logical basis, as taking into account that in the case of proposing the dissolution of the Saeima, a conflict between the President and the Saeima arises, the referendum shall decide whom to trust - the Saeima or the President of the State. When determining the quorum threshold, this conflict is not resolved and, therefore, efficient further functioning of these two institutions would be quite difficult.

It should be pointed out that the above mentioned President's order for proposing the dissolution of Parliament created a series of discussions among lawyers ${ }^{13}$. In addition, several individuals appealed to the Administrative Court for the annulment of the decision of the Central Electoral Commission No. 10 "The call for a referendum." The main discussions gave rise to the question whether the President had the right to issue the order for the dissolution of the Saeima so shortly before his presidential term expires. Valdis Zatlers' President's term of office ended on July 7, 2011, and thus it was virtually impossible to implement the mechanism enshrined by Article 50 of the Satversme that if in the referendum more than half of the votes are cast against the dissolution of the Saeima, then the President shall be deemed to be removed from office because his term had already expired. ${ }^{14}$ As already mentioned, the Latvian legislation does not set any limits neither for cases, in which the President may propose the dissolution of Parliament, nor for the time limits, consequently, only the President can make choices.

9 Latvijas Valsts Prezidenta Rīkojums Nr. 2.28 May, 2011 [interactive]. [accessed on 05-29-2011]. <http:// www.likumi.lv/doc. php?id=230900>.

10 2011.Gada 23.Jūlija Tautas Nobalsošana par 10.Saeimas Atlaišanu. [interactive]. [accessed on 07-232011]. <http://web.cvk.lv/pub/public/29957.html>.

11 In the history of Latvia, the Saeima has previously been dissolved, but it was not in accordance with the Constitution, but a coup d'état on 15 May in 1934, when the activities of the Satversme were suspended. It should be noted that in 1927 a certain Society collected signatures on a draft law "Law on recall of the second Saeima of the Republic of Latvia". This initiative did not succeed because the necessary 1,000 signatures were not collected to officially begin $1 / 10$ collection of voter signatures. See: Pleps, J., op. cit., p. 4.

12 The Latvian Constitution provides a total of 7 cases, in which the referendum is held.

13 Saeimas Atlaišana: Satversme un Neskaidrie Jautājumi. Jurista Vārds. 2011, 23(670): 3-7.

14 Bērziņš, R. Rīkojuma Nr. 2 Iespējamā Neatbilstība Satversmei. Jurista Vārds. 2011, 23(670): 5-7. 
The Administrative Court, after evaluating the application submitted to the Court, decided to ignore it, because the Court concluded that the decision of the Central Election Commission was not an independent decision, founding legal relations in the field of public administration, but it was only an organizational performance tool, subordinated to the order of the President. Also, the decision of the Central Election Commission did not focus on a new legal effect (even more so - for certain persons), as the opportunity to the people to vote in favour of the dissolution was not given by the decision of the Central Election Commission, but by the President's order. ${ }^{15}$

As already mentioned, a referendum was held on 23 July, 2011, which dissolved the Saeima, and the Central Election Commission announced new parliamentary elections, which, according to Article 48 of the Satversme, shall be held no later than two months after the date of the dissolution of the Saeima. On September 17, 2011, early elections were held in Latvia, which were the first early elections in the history of Latvia.

The legislature continuity principle is embedded in a regulatory framework of Latvia, which means that if the Saeima has been dissolved, the mandate of the members of the Saeima shall continue to take effect until the newly elected Saeima has convened, but the dissolved Saeima may only hold sittings at the request of the President - in this case, the agenda of such sittings shall be determined by the President. ${ }^{16}$

In the meantime, from the time, when the President has announced a proposal to dissolve the Saeima, and until it is dissolved in the referendum, parliamentary work takes place as usual, and only if in the referendum the Saeima has been dissolved, the Saeima has been convened and the agenda of sittings shall be determined by the President. Such a regulation is justified, because otherwise the dissolved Saeima still is able to accept a variety of irrational decisions. Moreover, taking into account that the institution of Presidential impeachment in Latvia has not been established yet and the Saeima has no limitations for removal of the President from office, such a rule prevents a theoretical possibility that in the meantime, until the new parliament has been convened, the dissolved Saeima can revenge the President by removing the President from office under the procedure provided by Article 51 of the Satversme. ${ }^{17}$

In practice, the parliament, work of which has been called into question and for which dissolution has been initiated, may still work for quite a long time, e.g., the 10th Saeima, since the President Valdis Zatlers announced the initiation of the dissolution of the Saeima on 28 May, 2011, has worked almost for five months - until 17 October, 2011, when the newly elected Saeima has convened.

As mentioned above, by the implementation of the creative function in the negative aspects, i.e. initiating the dissolution of the Saeima, the President runs the risk of losing

15 Administratīvās Rajona Tiesas 05.07.2011. Lēmums par Atteikšanos Pieņemt Pieteikumu. Jurista Vārds. 2011, 28(675): 8-10.

16 Pastars, E. Konstitucionālo Vērtību Aizsardzība Saeimas Atlaišanas Gadījumā. Jurista Vārds. 2011, 45(692): 2-4.

17 Article 51 of the Satverme, which enshrines the procedure for the removal of the President from the Office, states: "Upon the proposal of not less than half of all of the members of the Saeima, the Saeima may decide, in closed session and with a majority vote of not less than two-thirds of all of its members, to remove the President from Office." 
his office, because if more than half of the number of participants in the referendum proposed by the President on the dissolution of the parliament will not support the proposal, the President will automatically lose his office. Thus, the structure of the norms of the Satversme is constructed in a way, so that the result of the referendum will be an alternative - either the Saeima, or the President himself will be dismissed. The regulatory framework determined by Article 50 of the Satversme can be seen as the responsibility of the President of the State, according to which the President has proposed to dismiss an elected representative institution - the Saeima, and so if the voters in the referendum do not support the decision on the dissolution of the representative institution elected by the people, the President is responsible for the expression of such initiatives.

Already shortly after the adoption of the Satversme, Law Science has stated that the President should have the right to propose the dissolution of the Saeima without risk of losing his office. ${ }^{18}$ Such a proposal was expressed in the opinion of the Presidential Commission on Constitutional Law: "Opinion on the development of early elections mechanism of the Saeima", ${ }^{19}$ on the basis of which the President Valdis Zatlers on several occasions ${ }^{20}$ submitted to the Saeima legislative initiatives by offering to express Article 48 of the Satversme in a new version, by providing the President discretionary power to dismiss the Saeima without referendum. However, none of the initiatives was concluded with the adoption of appropriate amendments.

Previously, Law Science had made findings that the President of the State is likely to propose the dissolution of the Saeima only if the public discontent with the work of the Saeima gives sufficiently convincing evidence that the Saeima no longer acts in accordance with the will of the people. ${ }^{21}$ Also, in 2011, when the President proposed the dissolution of the parliament, the political situation in the country showed that the people as the sovereign are dissatisfied with the work of the Saeima. This was demonstrated by the referendum result, as $94.3 \%$ of the voters, who participated in a particular referendum, voted in favour of dissolution.

The laws and regulations do not require the President to include his motivation, why he has initiated a referendum on the dissolution of the Saeima, while at the same time it is expected that the President will communicate his motives to the people and they will be objective. ${ }^{22}$ On 28 May, 2011, when the President Valdis Zatlers came up with an order for the dissolution action, the order first was read on television and radio. Though the content of the order was very concise, which stated that: "On the basis of Article 48 of the Satversme of the Republic of Latvia I propose the dissolution of

18 Dišlers, K. Ievads Latvijas Valststiesību Zinātnē. Rīga: A. Gulbis, 1930, p. 177.

19 Ibid.

20 Valsts Prezidenta Konstitucionālo Tiesību Komisija. Viedoklis par Saeimas Priekšlaicīgu Vēlēšanu Mehānisma Pilnveidošanu. 2008 [interactive]. [accessed on 04-30-2008]. <http://www.president.lv/images/ modules/items/PDF/item_1680_KTK_30042008_Viedoklis_par_Saeimas_priekslaicigu_velesanu_mehanisma_pilnveidosanu.pdf $>$.

21 Dišlers, K., op. cit., p. 177.

22 Pleps, J. Kādā Veidā Var Atlaist Saeimu. Jurista Vārds. 2003, 45(301): p. 3. 
the Saeima", the President had already indicated in this speech certain motives, which formed the basis for such an order.

The President pointed out that the motives were related to the influence of oligarchs on adoption of various important decisions, e.g., the Saeima did not approve for the office the Prosecutor General and the judges that had been approvingly evaluated by the judge qualification collegiums and who had earlier, during their professional activities in the field of judicial power, adopted resolutions and judgments adverse to the so-called oligarchs. Moreover, public surveys evidenced that the Saeima enjoyed a very low level of trust in the society and only $10 \%$ of residents trusted it. ${ }^{23}$

After the President Valdis Zatlers made the statement on initiating the dissolution of the Saeima public, the former President G. Ulmanis also admitted that the issue of the dissolution of the Saeima had been, at times, the object of his thought as the President. Moreover, he admitted that he had prepared for the dissolution of the 6th Saeima shortly after it was elected if the Saeima had not approved the government of the candidate for the Prime Minister's office proposed as third in a row. ${ }^{24}$

In practice, the situation of recalling of the Saeima turned out quite interesting and somewhat predictable, because, as already noted, on 28 May, 2011, the President Valdis Zatlers proposed the dissolution of the 10th Saeima, but some days later, on 2 June, 2011, elections of the new President were held, in which the President Valdis Zatlers was also proposed as a candidate, and, thus, the 10th Saeima, the work of which was doubted by the President Valdis Zatlers, had to elect the new President. During the Presidential elections on 2 June, 2011, the President Valdis Zatlers did not receive the required support of 51 MPs and during the second stage of the elections Andris Bērzinšs was elected as the President with the support of 53 votes, however, based on initial forecasts he had less prospect to be elected. ${ }^{25}$ Considering that pursuant to Section 36 of the Satversme the President is elected by the Saeima in secret ballot, such result of the elections was not a surprise in the respective situation.

It should be added that the regulation of term of authority of the newly elected President is also peculiar in the event if the referendum for the dissolution of the Saeima is adverse for the President, i.e. if more than half of votes is against the dissolution of the Saeima and, thus, the President himself is dismissed. As noted already, Section 50 of the Satversme sets forth that in such event the Saeima would elect a new President for the remaining term of office of the dismissed President. Such regulation is quite specific, because, firstly, if the office of the President became vacant shortly before expiry of the term of authority of the President, then the newly elected President would

23 Valsts Prezidenta Valda Zatlera Pazinojums Latvijas Tautai. State President Institution, 2011 [interactive]. [accessed on 05-28-2011]. <http://www.president.lv/pk/content/?art_id=17535>.

24 Valsts Prezidenta Konstitucionālo Tiesību Komisija. Viedoklis par Saeimas Priekšlaicīgu Vèlēšanu Mehānisma Pilnveidošanu. 2008 [interactive]. [accessed on 04-30-2008]. <http://www.president.lv/images/ modules/items/PDF/item_1680_KTK_30042008_Viedoklis_par_Saeimas_priekslaicigu_velesanu_mehanisma_pilnveidosanu.pdf $>$.

25 Note: During the 1st stage of the elections V. Zatlers was supported by 43 MPs and A. Bērziņš by 50 MPs. During the second stage of the elections support for V. Zatlers remained unchanged, but 53 MPs voted for A. Bērziñš̆. 
be granted quite a short time for performance of his duties, and during such a short time the President, most likely, would not be able to affirm himself on this important position and would not manage to implement the priorities of his presidency.

Secondly, if the new President was elected for the remaining term of office of the previous President, it would create uncertainty of a legal nature with respect to repeated election of this President to the office. Namely, it is set forth in Section 39 of the Satversme that "the same person cannot be a President for more than eight years in a row". If the new President was elected for the remaining term of authority, it would be very difficult to fit into the limits of these 8 years, e.g., if, according to Section 50 of the Satversme, a person was elected to the office for the remaining term of office of the dismissed President, which is 1 year, and then he decided to run for the regular Presidential elections for 4 years and was elected, then in the aggregate such person would spend 5 years in the office of the President. However, he would be prevented from the possibility to run for the next elections, because then the person would already have exceeded the permitted 8 year term of the office. On the other hand, such person would have been left with 3 eventual years of presidency unused. Thus, the regulation set forth in Section 50 of the Satversme may, as to its merits, restrict the rights of the person to be elected for the office of the President for 8 years in a row, as set forth in Section 39 of the Satversme. The fact that such regulation is more optimal is indirectly evidenced by the approach dominating in the constitutional regulation of other countries of the world as well as that in the event of extraordinary elections the President is elected for a full term of the office. ${ }^{26}$

\section{Recalling of the Saeima}

On 8 April, 2009, the amendments to the Satversme were adopted. These amendments along with the previously described case of the dissolution provide another parliamentary termination type - recall of the Saeima. ${ }^{27}$

The Saeima procedure for the recalling is enshrined in Article 14 of the Satversme. It states that not less than one tenth of electors has the right to initiate a national referendum regarding recalling of the Saeima. If the majority of voters and at least two thirds of the number of the voters who participated in the last elections of the Saeima vote in the national referendum regarding recalling of the Saeima, then the Saeima shall be deemed recalled.

Unlike the first model considered above, when the Saeima is dissolved by the President's proposal, this model imposes restrictions, when people are not entitled to stimulate the dissolution of the Saeima. These cases are laid down in Article 14 of the Satversme and are as follows: "The right to initiate a national referendum regarding

26 E.g., it is directly stated in the Constitution of Greece (Article 32) and in the Constitution of the Portuguese Republic (Article 128).

27 The Satversme has been amended 11 times and this is by far the last amendment. These amendments came into effect on the 10th parliamentary gathering on 2 November, 2010. 
recalling of the Saeima may not be exercised one year after the convening of the Saeima and one year before the end of the term of office of the Saeima, during the last six months of the term of office of the President, as well as earlier than six months after the previous national referendum regarding recalling of the Saeima."

Thus, in this model the initiator of the early termination of the Saeima mandate is the people themselves, more specifically, not less than one tenth of the electors.

Efforts to strengthen the people's right in the Satversme to recall the Saeima have been already established. In the end of 2007, close to the Houses of Parliament a peaceful gathering took place, in which a large section of the public expressed its disappointment with the parliamentary and government work and requested the President to dissolve the Saeima, but the President at that time considered that it would not be the best option and the proposal for the dissolution did not follow. ${ }^{28}$ Taking into account that public discontent with the Saeima work was not lost, in 2008, the voters of Latvia, making use of the mechanism for initiative of the draft law provided by the Satversme, submitted the amendments to the Satversme initiated by the people to the Saeima, which provided the right of the people to initiate the dissolution of the Saeima. The submission of the draft of the amendment to the Constitution was initiated and coordinated by the nongovernmental organization - the Latvian Free Trade Union. After examining the draft in the Saeima, the Saeima rejected the draft of the amendment to the Constitution initiated by the people and, therefore, the draft, according to Article 78 of the Satversme, was to be submitted to national referendum. ${ }^{29}$ On 2 August, 2008, a referendum on the adoption of the amendment to the Constitution initiated by the voters was held. In the referendum turnout was insufficient and, therefore, the draft was not adopted (the referendum was attended by $42 \%$ of voters, from which an overwhelming $96 \%$ of the voters had voted in favour of the amendment). ${ }^{30}$ Taking into account that a significant portion of the society had expressed the wish that the people have the right to initiate the dissolution of the Saeima, after the referendum the President Valdis Zatlers addressed the Saeima to develop Constitutional amendments, which would provide the right of the people to recall the Saeima, stating that otherwise he would initiate the dissolution of the Saeima. ${ }^{31}$ The Saeima did it quite operatively and already on 8 April, 2009, such a new mechanism of early termination of the Saeima mandate was enshrined in the Satversme. It should be noted that the above mentioned amendment to the Constitution initiated by the people was quite sceptically evaluated by legal experts, as it was not perfect from a legal standpoint.

Thus, since the entry into force of this amendment, the number of cases of the early termination of the Saeima mandate has been extended, as in addition to the existing

28 Švarcs, L. Valsts Prezidents Ierosina Saeimas Atlaišanu. Jurista Vārds. 2011, 23(670): 1-2.

29 Note: Article 78 of the Satversme states that if the Saeima does not adopt the draft submitted by the people, it shall be then submitted to a national referendum.

30 An amendment to the Constitution submitted for a national referendum shall be deemed adopted if at least half of the electorate has voted in favour (Article 79 of the Satversme).

31 Balodis, R.; Kārkliṇa, A.; Danovskis, E. Latvijas Konstitucionālo un Administratīvo Tiesību Attīstība pēc Neatkarības Atjaunošanas. Journal of the University of Latvia. Law. 2012, 3: 41-105. 
legislation, which provided the right to dissolve the Saeima under the procedures provided by Article 48 of the Satversme, the voters now have the right to recall the Saeima, which means that the people themselves can initiate a referendum on the dissolution of the Saeima, and it is not necessary that the President starts this process under the procedures provided by Article 48 of the Satversme. The right of voters to initiate and decide on recall of the parliament is a rare phenomenon elsewhere in the world.

The procedure, in which the electorate initiates the recalling of the Saeima, is governed in more detail by the law "On National Vote, Initiating the Laws and Initiative of European Citizens". ${ }^{32}$ Initially, during the first stage not less than 10,000 citizens of Latvia entitled to vote have the right to deliver a proposal to organise the national vote for the recalling of the Saeima to the Central Election Commission. Since the amendments to the law adopted in the end of 2012, for promotion of such process the electorate must establish a special group of initiative that coordinates this process (the group of initiative may be a political party or a union established by not less than 10 electors). If the CEC established that the proposal for organisation of the national vote for the recalling of the Saeima has been signed by not less than 10,000 citizens of Latvia entitled to vote, then the second stage follows, which includes collection of signatures organised and paid for by the state. If within the defined period for the collection of the signatures the idea of organising the national vote is supported by at least $1 / 10$ of the electorate, then the national vote (referendum) is organised in the country, in which the electorate must decide for or against the recalling of the Saeima. Such regulation will be in force until 1 January, 2015, because afterwards it is envisaged that the electorate itself must collect $1 / 10$ of the signatures. This will, of course, make the process of collecting the signatures a little more complicated, however, the novelty will be that the electronic collection of the signatures will be provided and notarisation of the signatures will be made easier. Individual opinions about the need to propose the recalling of the Saeima have been heard so far, e.g., not long ago, in May 2013, some union that was against Latvia joining the Euro currency and supporting retaining the LVL announced that it will propose the recalling of the Saeima because all factions support joining the Euro-zone ${ }^{33}$, however, the required number of 10, 000 signatures has not been collected so far.

To avoid campaigns aimed at achieving the recalling of the Saeima in an illegitimate and unlawful manner, the law "On National Vote, Initiating the Laws and Initiative of European Citizens" sets forth a strict regulation for the agitation campaigns.

It should be noted that in 2007 and 2008, when the public discontent with the Saeima work was particularly high and extensive discussions on the dissolution of the Saeima took place, certain political parties tried to initiate the proposal to strengthen the mechanism of self-dissolution of the Saeima in the Satversme (a mechanism similar

32 Par Tautas Nobalsošanu, Likumu Ierosināšanu un Eiropas Pilsoṇu Iniciatīvu. Latvijas Vēstnesis. 1994, No. 47(178).

33 Biedrībai Lauj Vākt Parakstus Referenduma Rīkošanai par 11.Saeimas Atsaukšanu 'Lata Likvidēšanas' dēl. Delfi. 2013 [interactive]. [accessed on 05-29-2013]. <http://www.delfi.lv/news/national/politics/ biedribai-lauj-vakt-parakstus-referenduma-rikosanai-par-11saeimas-atsauksanu-lata-likvidesanasdel.d?id=43356905>. 
to that which is defined by Article 58 of the Lithuanian Constitution) ${ }^{34}$, but after the following discussions no further development took place. Some advantages indicated for such regulation were that if the Saeima voluntarily agreed to step down, then organising the national vote would not be required and new elections would be held automatically. This mechanism would be financially more beneficial for the state and more operative, though the decisive counter-argument against adoption of such regulation was that such mechanism could also be used by a coalition to select a moment of premature elections favourable for it and thus strengthen its positions.

The legislation of Latvia only provides for the possibility of dissolve or recall of the Saeima. In Latvia, there is no mechanism that would allow voters to recall individual members of Parliament. The Satversme has enshrined the so-called clear mandate Article 14 of the Saeima states: "The electors may not recall any individual member of the Saeima."

However, it should be noted that this regulation does not make the deputy absolutely irresponsible because if the member has breached the legal requirements, his mandate would be terminated before the deadline. These cases are determined by the Saeima Order. In accordance with Article 18 of this law, the member will automatically be excluded from the Saeima at the time of entry into force of conviction. In addition to this, other MPs can also vote for the exclusion of the deputy from the Saeima in certain cases. These cases are exhaustively listed and include the following: the deputy is elected by violation of election law rules, does not speak the language to the extent necessary to his professional duties, holds the position which is incompatible with the parliamentary office, has not visited more than half of the sittings for unjustified reasons during one session, has committed offense in the state of irresponsibility or has been declared incapacitated.

\section{Conclusions}

1. During the last 20 years, various mechanisms have been established in Latvian constitutional law that expand the rights of the nation, as a sovereignty, to participate in adoption of decisions: several new events of direct democracy have been established in the Satversme, including providing the possibility for the nation itself to initiate the resolution for recalling the Parliament, because until then the only way to terminate authority of the Saeima was the procedure, pursuant to which the President could initiate the national vote for dissolution of the Saeima, and in such national vote the electorate decided whether to dissolve the Saeima or not. Implementation of this mechanism for dissolving the Saeima in practice may possibly be hindered by the construction that if the majority of the electorate does not support dissolving the Saeima, then the President would be deemed dismissed. Due to the above reason, the experts, including the former

34 The Constitution of the Republic of Lithuania. [interactive]. [accessed on 03-28-2013]. <http://www.lrkt. 1t/Documents2_e.html>. 
Presidents, had proposed the Saeima several times to amend the Satversme by offering a regulation that the President would be granted the right to dissolve the Saeima without risking his office, like it is done in many other European countries. However, the Saeima has not accepted this proposal.

2. The only time in the history of Latvia when the Saeima was dissolved in a constitutional manner was in 2011, and in this situation there was an interesting fact that when the President proposed the national vote for dissolving the Saeima, he did not risk his office in the procedure set forth in Section 48 of the Satversme, considering that only some months were remaining until the end of term of his authority, and even if the nation had supported the Saeima, and not the President, in the referendum, in reality the President would not be dismissed because his term of the office would have expired. It should be noted, though, that the President of that time essentially accepted certain political risk about this decision, because the President was proposed as a candidate for the office for the second term, but, as it could have been foreseen already, the 10th Saeima, the dissolution of which Zatlers had proposed on May 28, 2011, some days later, on June 2, 2011, did not elect Zatlers for the President's office repeatedly on the Presidential elections.

3. The Latvian nation is increasingly actively using its rights granted by the Satversme, including the rights to file draft laws. To some extent, also based on the activity of the public, the electorate won itself the right to initiate recalling of the Saeima. So, if the President does not opt for initiating dissolving the Saeima, since 2010 $1 / 10$ of the electorate have the right to initiate the referendum for recalling the Saeima themselves.

4. The rights of the electorate to initiate recalling of the Saeima are limited though; the Satversme sets forth several events, when the electorate do not have the right to initiate recalling of the Saeima, whereas the rights of the President to initiate national vote for dissolving the Saeima are not restricted by any conditions and it is only an issue of choice of the President, and the President may also implement such rights when little time has remained until the end of his Presidency (theoretically, the President could initiate dissolving the Saeima on the last day of his authority, as well).

5. There is a mechanism established in Latvia that only the nation, as a sovereignty, is entitled to both elect the Saeima and adopt the decision on premature termination of its authority. In both cases, the mechanism of dissolving the Saeima set forth in Section 48 of the Satversme and the procedure of recalling the Saeima set forth in Section 14 , the final decision on whether the authority of the Parliament should be terminated prematurely is adopted only by the nation as a sovereignty.

6. Both established pre-war scientists and modern constitutional law experts considered dissolving the Saeima as the so-called snoozing prerogative, however, the President's order of 2011 regarding initiating dissolving the Saeima and the subsequent referendum, in which the electorate dissolved the Saeima, demonstrated that it is an effective mechanism applicable in practice to improve the work of the Parliament. 
Moreover, it will undoubtedly play a preventive role in the activities of future Parliaments, as well.

\section{References}

Administratīvās Rajona Tiesas 05.07.2011. Lēmums par Atteikšanos Pieñemt Pieteikumu. Jurista Vārds. 2011, 28(675): 8-10.

Balodis, R.; Kārkliņa, A.; Danovskis, E. Latvijas Konstitucionālo un Administratīvo Tiesību Attīstība pēc Neatkarības Atjaunošanas. Journal of the University of Latvia. Law. 2012, 3: 41-105.

Bērziņš, R. Rīkojuma Nr. 2 Iespējamā Neatbilstība Satversmei. Jurista Vārds. 2011, 23(670): 5-7.

Biedrībai Lauj Vākt Parakstus Referenduma Rīkošanai par 11.Saeimas Atsaukšanu 'Lata Likvidēšanas' dēlı. Delfi. 2013 [interactive]. [accessed on 05-29-2013]. <http://www. delfi.lv/news/national/politics/biedribailauj-vakt-parakstus-referenduma-rikosanaipar-11saeimas-atsauksanu>.

Dišlers, K. Ievads Latvijas Valststiesību Zinātnē. Rīga: A. Gulbis, 1930, p.177.

Iljanova, D. The Constitutional Law of the Republic of Latvia. Constitutional Law of 10 EU Member States. The 2004 Enlargement. Kluwer Law International, 2006, p. v-3.

Latvijas Valsts Prezidenta Rīkojums Nr. 2. 28 May, 2011 [interactive]. [accessed on 05-29-2011]. <http://www.likumi.lv/doc. php?id $=230900>$.

Par Tautas Nobalsošanu, Likumu Ierosināšanu un Eiropas Pilsoņu Iniciatīvu. Latvijas Vēstnesis. 1994, No. 47(178).

Pastars, E. Konstitucionālo Vērtību Aizsardzība Saeimas Atlaišanas Gadījumā. Jurista Vārds. 2011, 45(692): 2-4.
Pleps, J. Kādā Veidā Var Atlaist Saeimu. Jurista Vārds, 2003, 45(301): 3-6.

Saeimas Atlaišana: Satversme un Neskaidrie Jautājumi. Jurista Vārds. 2011, 23(670): 3-7.

Satversme of the Republic of Latvia, Latvijas Vēstnesis. 1993, No. 43.

Švarcs, L. Valsts Prezidents Ierosina Saeimas Atlaišanu. Jurista Vārds. 2011, 23(670): 1-2.

The Constitution of the Republic of Lithuania. [interactive]. [accessed on 03-28-2013]. $<$ http://www.lrkt.lt/Documents2_e.html $>$.

Valsts Prezidenta Konstitucionālo Tiesību Komisija. Viedoklispar Saeimas Priekšlaicīgu Vēlēšanu Mehānisma Pilnveidošanu. 2008 [interactive]. [accessed on 04-30-2008]. $<$ http://www.president.lv/images/modules/ items/PDF/item_1680_KTK_ 30042008 Viedoklis_par_Saeimas_priekslaicigu_ velesanu_mehanisma_pilnveidosanu.pdf $>$.

Valsts Prezidenta Valda Zatlera Pazinojums Latvijas Tautai. State President Institution. 2011 [interactive]. [accessed on 05-28-2011]. $<\mathrm{http}: / / \mathrm{www}$. president.lv/pk/content/?art $\mathrm{id}=17535>$.

2011.Gada 23.Jūlija Tautas Nobalsošana par 10.Saeimas Atlaišanu. [interactive]. [accessed on 07-23-2011]. <http://web.cvk. lv/pub/public/ 29957.html>.

Saharov, A.H. Institut Prezidenstva v Sovremennom Mire [The Institute of President in Contemporary World]. Moskva: Juridicheskaja Literatura, 1994. 


\title{
SEIMO İGALIOJIMŲ NUTRAUKIMAS LATVIJOJE: TEISINIS REGULIAVIMAS IR PRAKTIKA
}

\author{
Annija Kārkliņa
}

Latvijos universitetas, Latvija

Santrauka. Latvijos konstitucineje teiseje per paskutinius 20 metu buvo i̇tvirtinti ivairūs mechanizmai, išplečiantys tautos kaip suvereno teises dalyvauti priimant nutarimus. Konstitucijoje yra ịtvirtinti keli nauji tiesiogines demokratijos atvejai, numatant galimybe tautai pačiai inicijuoti nutarima dèl parlamento paleidimo, nes iki tol vienintelis büdas anksčiau laiko nutraukti Seimo igaliojimus buvo valstybès prezidento teise pasiūlyti tautai balsuoti del Seimo iggaliojimu nutraukimo, ir rinkejjai šiame tautos balsavime turejo spręsti, ar paleisti Seima. Igyvendinti šç Seimo atleidimo mechanizma gali nepavykti, jeigu dauguma rinkejju neremia Seimo igaliojimu nutraukimo, - tokiu atveju atleistu bus laikomas pats valstybès prezidentas. Dél minetos priežasties ekspertai, t. y. buvę valstybés prezidentai, kelis kartus siūle Seimui keisti Konstitucija numatant, kad valstybès prezidentui bütu suteikta teise paleisti parlamenta, nerizikuojant savo pareigomis, panašiai kaip tai yra daugelyje kitu Europos šaliu. Tačiau šio pasiülymo Seimas neakceptavo.

Latvijos istorijoje Seimo igaliojimai buvo nutraukti vieninteli karta - 2011 metais, ir sioje situacijoje idomi buvo ta aplinkybè, kad valstybès prezidentas, siülydamas tautai balsuoti del Seimo paleidimo, nerizikavo savo pareigomis Konstitucijos 48 straipsnyje nustatyta tvarka, nes iki jo paties igaliojimu termino pabaigos buvo likę keli menesiai, ir netgi tokiu atveju, jeigu tauta referendume bütu paremusi Seima, o ne valstybes prezidenta, valstybès prezidentas nebütu atleistas, nes jo igaliojimu terminas bütu pasibaigęs. Tuometinis valstybès prezidentas šiuo nutarimu prisiemè tam tikra politine rizika, nes buvo iškèlęs savo kandidatüra prezidento rinkimuose antrai kadencijai, tačiau, kaip ir buvo galima numatyti, 10-asis Seimas, kurį paleisti V. Zatlers buvo pasiülęs $2011 \mathrm{~m}$. gegužes 28 d., po keliu dienu - birželio2 $d$., prezidento rinkimuose $V$. Zatlerio pakartotinai prezidentu neišrinko.

Seimo paleidimas sukèle daugybę konstituciniu ir politiniu diskusiju, nes lakoniškas konstitucijos reguliavimas $i$ kai kuriuos klausimus nedave aiskiu atsakymu, ir, reikia manyti, 2011 metu Seimo atleidimo patirtimi bus pasinaudota kaip konstituciniu papročiu panasiais atvejais. İdomu, kad Seimas, kuri atleisti buvo pasiūlyta $2011 \mathrm{~m}$. gegužès $28 \mathrm{~d}$., iki to momento, kai jis buvo atleistas tautos balsavimu, - t. y. iki $2011 \mathrm{~m}$. liepos 23 d., prieme kelis reikšmingus nutarimus ir - išrinko kita valstybès prezidenta.

Latvijos tauta vis aktyviau naudojasi Konstitucijoje numatytomis teisemis - tarp ju ir teise pateikti įstatymu projektus. Tam tikru mastu rinkejjai išsikovojo teisę siūlyti paleisti Seima. Taigi, jeigu valstybès prezidentas neapsigalvos del Seimo atleidimo iniciatyvos, nио 2010 metu 1/10 rinkèju turi teise patys inicijuoti referenduma dèl Seimo paleidimo.

Rinkejju teise inicijuoti Seimo paleidima vis delto yra ribota - Konstitucija nurodo kelis atvejus, kai rinkejjai neturi teisès siūlyti nutraukti Seimo igaliojimu, tačiau valstybès prezidento teise siülyti tautos balsavima del Seimo paleidimo nera ribota - tai yra tiktai paties prezidento nusistatymo klausimas ir prezidentas šia teise gali igyvendinti ir tuomet, kai iki 
jo kadencijos pabaigos liko visǐ̌kai nedaug laiko (teoriškai prezidentas galètu siülyti Seimo paleidima taip pat ir paskutine igaliojimu termino diena).

Latvijoje tiktai tauta kaip suverenas turi teisę rinkti Seima arba priimti nutarima dèl jo priešlaikinio igaliojimu nutraukimo. Abiem atvejais - ir Konstitucijos 48 straipsnyje numatytame Seimo paleidimo mechanizme, ir jos 14 straipsnyje ìtvirtintoje Seimo atšaukimo procedūroje galutini nutarima dèl parlamento igaliojimu nutraukimo anksčiau termino priima tiktai tauta kaip suverenas. Skirtingos yra abieju mechanizmu igyvendinimo prielaidos ir procedüros, tačiau abiem atvejais galutini nutarima priima rinkèjai referendumu.

Autoritetingi prieškario laiku mokslininkai ir šiu dienu konstitucinès teisés ekspertai Seimo paleidima laiko „snaudžiančia“ prerogatyva, tačiau 2011 metu valstybès prezidento potvarkis dèl siülymo atleisti Seima ir paskesnis referendumas, kuriame rinkejjai paleido Seima, parode, kad tai yra efektyvus ir praktikoje taikomas parlamento darbo gerinimo mechanizmas, be to, neabejotinas jo prevencinis poveikis tolesnei parlamentu veiklai.

Reikšminiai žodžiai: parlamentas, Seimas, parlamento paleidimas, parlamento igaliojimu atšaukimas, parlamentaro mandatas, prezidentas, Konstitucija.

Annija Kārkliṇa, Latvijos univesiteto Teisès fakulteto prodekanè, docentė, socialinių mokslų daktarè (teisès krypties). Mokslinių tyrimų kryptys: konstitucinè ir darbo teisė.

Annija Kārkliņa, doctor of social sciences (Law), University of Latvia, Faculty of Law,Vice-Dean, associated proffeso. Research interests: constitutional law and labour law. 